\title{
KEBAHAGIAAN PADA WANITA DEWASA MADYA YANG MELAJANG
}

\author{
Sindhy Mariam Magdalena Pello ${ }^{1}$, Christiana Hari Soetjiningsih ${ }^{2}$ \\ Email: sindhymaria@gmail.com ${ }^{1}$ \\ Fakultas Psikologi Universitas Kristen Satya Wacana Salatiga ${ }^{1,2}$
}

\begin{abstract}
Happiness is a concept that relate to the emotion and positive activities felt by each individual except for the single people. The purpose of this research is to know the illustration of happiness to the adult females who decided to remain single and the influenced factors of happiness. Qualitative research method is used with phenomenological approach. The participants of this research are two adults'females 40-65 years old who decided to remain single. Interpretative phenomenological analysis (IPA) is used for the data analysis technique. The results of this research showed that adults females who decided to remain single still felt happiness through the positive relationship with others by doing things or activities that they liked, finding the meaning of their days, and having optimism and resilience attitude. The most influenced factor of happiness is religiosity.
\end{abstract}

Keywords: Happiness; Adult Female; Single; Religiousity; Success.

\begin{abstract}
Abstrak
Kebahagiaan merupakan konsep yang mengacu pada emosi serta aktifitas positif yang dirasakan oleh setiap individu tidak terkecuali bagi individu yang hidup melajang. Penelitian ini bertujuan untuk mengetahui gambaran kebahagiaan pada wanita dewasa yang memutuskan untuk hidup melajang serta faktor yang memengaruhi kebahagiaan. Peneliti menggunakan metode penelitian kualitatif dengan pendekatan fenomenologi. Penelitian ini melibatkan dua orang partisipan dewasa madya berusia 40 - 65 tahun yang memutuskan untuk hidup melajang. Teknik analisis data dalam penelitian ini menggunakan Interpretative Phenomenological Analysis (IPA). Hasil penelitian ini menunjukkan bahwa wanita madya yang memutuskan untuk hidup melajang tetap dapat merasakan kebahagiaan melalui terjalinnya hubungan yang positif dengan orang lain, melibatkan diri secara penuh pada kegiatan-kegiatan yang disukai, menemukan makna dalam keseharian, memiliki sikap optimis dan resiliensi. Faktor yang berpengaruh kuat pada kebahagiaan yaitu religiusitas.
\end{abstract}

Kata Kunci: Kebahagiaan; Wanita Dewasa Madya; Lajang; Religiusitas, Sukses.

PENDAHULUAN

Emansipasi

merupakan

kemerdekaan untuk memperoleh

persamaan derajat, hak serta kedudukan.

Di Indonesia, emansipasi memberikan hak

bagi wanita untuk memiliki pendidikan

yang tinggi serta kesempatan untuk mengembangkan karier. Adanya kesempatan ini, wanita yang fokus terhadap pendidikan dan karier yang dimiliki menjadi pribadi yang mandiri serta sukses. Tetapi disisi lain, wanita yang semakin fokus terhadap pendidikan serta kariernya dan menjadi sukses serta mandiri akan memutuskan untuk menunda pernikahan.

Fenomena yang terjadi di Indonesia saat ini adalah wanita karier yang berstatus lajang dan belum menikah meskipun sudah memasuki masa dewasa madya. Hal ini terbukti dari hasil data yang dilakukan oleh Badan Pusat Statistik (BPS, 2016) yang mengukur tentang angka pernikahan di Indonesia selama tahun 2012 sampai dengan tahun 2015 menemukan hasil bahwa angka 
pernikahan mengalami penurunan sepanjang tahun sampai pada tahun 2015 . Selain itu menurut Indeks Kebahagiaan Indonesia (IKI) yang dilakukan oleh BPS pada tahun 2017 menunjukkan bahwa orang yang belum menikah memiliki angka indeks kebahagiaan yang lebih tinggi dibanding dengan penduduk yang memiliki status perkawinan (Sari, 2017).

Wanita yang memutuskan untuk belum menikah disebut juga dengan wanita lajang. Stein (dalam Sutanto, 2010) mendefinisikan status lajang berupa status seseorang yang tidak menikah, tidak memiliki teman hidup dan tidak melakukan hubungan secara fisik, sosial, maupun emosional. Menurut Hurlock (1999) ada beberapa faktor yang membuat orang dewasa memilih untuk hidup melajang dan tidak mau menikah. Faktorfaktor tersebut antara lain yaitu: mempunyai kepercayaan bahwa mobilitas sosial akan lebih mudah diperoleh apabila dalam keadaan lajang daripada setelah menikah, memiliki keinginan untuk berkarier pada bidang yang menuntut jam kerja tanpa batas serta banyak bepergian, besarnya kesempatan untuk meningkatkan jenjang karier, memiliki kebebasan untuk mengubah dan melakukan percobaan dalam pekerjaan dan gaya hidup, sering gagal dalam mencari pasangan, tidak mau memikul tanggung jawab perkawinan, mempunyai tanggung jawab keuangan dan waktu untuk orangtua serta saudarasaudaranya, jarang memiliki kesempatan untuk berjumpa dan berkumpul dengan lawan jenis yang dianggap cocok dan sepadan, penampilan yang tidak menarik, memiliki cacat fisik atau penyakit, kekecewaan yang pernah dialami karena kehidupan keluarga yang tidak bahagia pada masa lalu dan melihat pengalaman pernikahan yang tidak membahagiakan yang dialami oleh temannya.

Keputusan wanita madya untuk hidup melajang menunjukkan wanita madya sudah tidak melakukan beberapa tugas perkembangan pada masa dewasa awal dan madya. Menurut Havighrust (dalam Hurlock, 1999) tugas perkembangan pada masa dewasa awal yaitu memilih pasangan, memiliki anak dan membina sebuah keluarga. Selain itu menurut Havighrust (dalam Hurlock, 1999) tugas perkembangan dewasa madya yaitu membantu anak-anak remaja belajar untuk menjadi orang dewasa yang bertanggung jawab, mengembangkan kegiatan-kegiatan pengisi waktu senggang untuk orang dewasa, menghubungkan diri sendiri dengan pasangan hidup sebagai suatu individu, menerima dan menyesuaikan diri dengan perubahan- 
perubahan fisiologis yang terjadi, mencapai dan mempertahankan prestasi yang memuaskan dalam karier dan pekerjaan, serta menyesuaikan diri dengan orang tua yang semakin tua. Dari tugastugas perkembangan yang harus dicapai, terlihat wanita dewasa madya yang memutuskan untuk hidup melajang tidak memenuhi dua tugas perkembangannya yaitu membantu anak-anak remaja belajar untuk menjadi orang dewasa yang bertanggung jawab dan menghubungkan diri sendiri dengan pasangan sebagai suatu individu.

Tugas-tugas

perkembangan

memegang peranan penting dalam menentukan perkembangan seseorang kearah yang normal maka apapun yang menghambat penguasaan sesuatu dapat dianggap sebagai bahaya potensial (Hurlock, 1999). Menurut Hurlock (1999) setiap individu yang tidak dapat memenuhi setiap tugas perkembangannya yaitu belum menikah maka akan mengalami konsekuensi-konsekuensi, yang pertama terdapat pertimbanganpertimbangan sosial yang kurang menyenangkan dari masyarakat sekitar yang memunculkan stigma-stigma yang mengakibatkan kurangnya penilaian diri dan konsekuensi kedua yaitu individu mengalami ketertinggalan dari kelompok sebayanya.

Wanita madya yang belum menikah mendapatkan tekanan dan pelabelan atau stigma negatif dari masyarakat sekitar. Hal ini terbukti dari hasil penelitian yang dilakukan oleh Septiana (2013) pada perempuan lajang dewasa madya berjumlah 6 partisipan yang menunjukkan bahwa mendiami posisi sebagai perempuan dewasa lajang bagi para partisipan penelitian ini telah mendatangkan stigma. Pengalaman stigma terhadap perempuan dewasa lajang yang dihadapi para partisipan penelitian ini adalah julukan sebagai "perawan tua", "tidak laku", dan "sudah lewat masanya" yang mereka dengar secara langsung maupun tidak langsung. Pengalaman mendapatkan stigma ini telah berdampak pada kondisi psikologis para partisipan, diantaranya adalah perasaan tertekan karena dibombardir dengan pertanyaanpertanyaan dan desakan untuk segera menikah. Posisi sebagai perempuan dengan status lajang yang berbeda dari kebanyakan perempuan seusianya yang telah menikah juga menyebabkan sebagian partisipan penelitan ini mendambakan pernikahan. Para partisipan merasakan kesepian pada momen-momen 
tertentu kehidupan mereka dan mengharapkan hadirnya pasangan hidup.

Fenomena dari penelitian diatas yang berlokasi di Surabaya menunjukkan bahwa wanita madya yang memutuskan untuk hidup melajang dan tidak terikat dalam ikatan pernikahan akan menghadapi tekanan-tekanan sosial, stigma yang negatif dari masyarakat, serta harus memenuhi desakan keluarga beserta teman-teman untuk segera menikah. Pernikahan sangat berhubungan erat dengan kebahagiaan (Seligman, 2005). Seligman (2013) menyatakan bahwa kebahagiaan sendiri dapat dianalisis kedalam 3 unsur yang berbeda yaitu emosi positif, keterlibatan dan makna.

Menurut Seligman (2002) setiap individu memiliki faktor yang berbeda sehingga bisa mendatangkan kebahagiaan. Faktor-faktor tersebut adalah uang, pernikahan, kehidupan sosial, emosi negatif, usia, kesehatan, pendidikan, agama dan jenis kelamin. Terdapat lima aspek utama kebahagiaan yang sejati menurut Seligman (2005) yaitu: Terjalinnya hubungan positif dengan orang lain, keterlibatan penuh, penemuan makna dalam keseharian, optimisme yang realistis, dan resiliensi

Kebahagiaan orang yang menikah memberikan efek pada panjang usia dan

wanita maupun pria. Kebahagiaan berhubungan erat dengan penilaian positif seseorang terhadap hidupnya. Menurut Myers (dalam Harrington, 2000) orang yang bahagia lebih cenderung untuk ingin menikah daripada orang yang tidak bahagia.

Berdasarkan fenomena dan hasil wawancara yang dilakukan kepada kedua partisipan wanita madya di Kupang pada bulan November 2018, menunjukkan bahwa partisipan memenuhi beberapa aspek dari kebahagiaan yaitu memiliki relasi sosial yang baik dengan tetangga, rekan kerja, keluarga dan orang disekitarnya. Kedua partisipan juga memiliki keterlibatan yang penuh terhadap pekerjaan mereka serta memiliki sikap optimis yang realistis terhadap masa depan. Kedua partisipan memiliki pekerjaan, karier yang baik serta berkecukupan dalam hal materi. Selain itu, kedua partisipan sama-sama sudah memutuskan untuk hidup melajang dan keputusan kedua partisipan untuk hidup melajang telah diterima oleh orang-orang terdekat seperti keluarga, rekan kerja dan tetangga.

Berdasarkan latar belakang dari penelitian sebelumnya diatas terlihat bahwa adanya perbedaan kriteria 
partisipan. Penelitian sebelumnya menggunakan partisipan seorang pria dan wanita madya dengan tipe lajang involuntary stable single, tidak memiliki pekerjaan dan memiliki kekurangan fisik dan psikis. Selain itu adanya perbedaan antara konsep kebahagiaan menurut Seligman (2005) yang mengatakan bahwa pernikahan sangat berhubungan erat dengan kebahagiaan dengan penelitian sebelumnya yang menunjukkan bahwa meskipun tidak menikah tetapi masih bisa merasakan kebahagiaan. Hal-hal diatas membuat peneliti semakin tertarik dan fokus untuk melakukan penelitian pada partisipan wanita untuk mengetahui gambaran kebahagiaan pada wanita dewasa yang memutuskan untuk hidup melajang serta faktor yang memengaruhi kebahagiaan.

\section{METODE PENELITIAN}

Penelitian ini dilakukan dengan menggunakan metode kualitatif dengan mempertimbangkan kekhususan masalah serta ketersediaan jumlah partisipan dalam penelitian. Peneliti ingin melakukan penelitian pada wanita untuk mengetahui seperti apakah gambaran kebahagiaan pada wanita dewasa madya yang memutuskan untuk hidup melajang serta faktor yang memengaruhi kebahagiaan.
Partisipan pada penelitian ini dipilih dengan menggunakan metode purposive sampling dengan kriteria wanita dewasa madya yang memiliki rentang usia 40 sampai dengan 55 tahun, memutuskan untuk hidup melajang masuk dalam tipe lajang voluntary stable singles, belum pernah menikah, memiliki pekerjaan dan jabatan pada pekerjaan.

\begin{tabular}{|c|c|c|}
\hline Partisipan & $\begin{array}{c}\text { Partisipan } \\
\text { I }\end{array}$ & $\begin{array}{c}\text { Partisipan } \\
\text { II }\end{array}$ \\
\hline Nama & E.T & C.L \\
\hline Usia & 54 tahun & 52 tahun \\
\hline Pekerjaan & $\begin{array}{c}\text { Dokter } \\
\text { Spesialis }\end{array}$ & Supervisior \\
\hline Agama & $\begin{array}{c}\text { Kristen } \\
\text { Protestan }\end{array}$ & $\begin{array}{c}\text { Kristen } \\
\text { Protestan }\end{array}$ \\
\hline $\begin{array}{c}\text { Waktu } \\
\text { wawancara } \\
1\end{array}$ & $\begin{array}{l}28 \text { Februari } \\
2019\end{array}$ & $\begin{array}{c}24 \\
\text { Februari } \\
2019\end{array}$ \\
\hline $\begin{array}{c}\text { Waktu } \\
\text { wawancara } \\
2\end{array}$ & $\begin{array}{c}\text { 01 Maret } \\
2019\end{array}$ & $\begin{array}{c}25 \\
\text { Februari } \\
2019\end{array}$ \\
\hline
\end{tabular}

Pengumpulan data yang dilakukan pada penelitian ini menggunakan wawancara dengan pedoman wawancara yang tidak diikuti secara ketat. Pertanyaan wawancara yang diberikan tidak selalu sesuai dengan pedoman wawancara yang ada tetapi megikuti dinamika yang berkembang selama proses wawancara berlangsung. Pedoman wawancara yang diberikan kepada partisipan memuat data diri, keseharian, permasalahan yang dihadapi partisipan serta berdasarkan pada aspek-aspek kebahagiaan yaitu hubungan positif dengan orang lain, keterlibatan penuh partisipan dalam kehidupannya, 
menemukan makna dalam kesehariannya, optimisme yang realistis dan resiliensi. Alat pengumpulan data yang digunakan dalam penelitian ini adalah alat perekam suara dan buku catatan. Proses wawancara diawali dengan membangun rapport terlebih dahulu. Penelitian ini dilakukan di Kota Kupang, Nusa Tenggara Timur.

Data dianalisis menggunakan metode Interpretative Phenomenalogycal Analysis (IPA) yang dikemukakan oleh Smith dan Osborn (Smith, 2009). Penelitian ini menggunakan metode validasi responden (Herdiansyah, 2015).

\section{HASIL DAN PEMBAHASAN}

Penelitian ini berhasil mengungkapkan tema utama kebahagiaan yang dikemukakan oleh Seligman (2005) yaitu hubungan positif dengan orang lain, keterlibatan penuh, penemuan makna dalam keseharian, optimisme yang realistis dan resiliensi serta faktor yang memengaruhi kebahagiaan yaitu religiusitas.

\section{Hubungan Positif dengan Orang Lain}

Berdasarkan hasil data yang diperoleh, P1 dan P2 sama-sama memiliki hubungan positif dengan orang-orang disekitar mereka. Kedua partisipan memiliki hubungan yang baik dengan kedua orangtua, saudara dan rekan kerja. Kedua partisipan sama-sama membutuhkan peran orang terdekat untuk memberikan dukungan, bantuan dan perhatian. Hal ini sejalan dengan teori konvoi sosial menurut Kahn dan Antonucci (dalam Papalia, 2009) yang berpendapat bahwa orang-orang berpindah melalui kehidupan yang dikelilingi oleh lingkaran teman dan keluarga dekat dengan berbagai kadar kedekatan yang dapat mereka andalkan untuk bantuan, kesejahteraan, dan dukungan sosial.

\section{Keterlibatan Penuh}

Selain terlibat secara penuh pada pekerjaan, kedua partisipan juga samasama memiliki waktu untuk melakukan aktivitas kesukaan mereka. P1 lebih senang menghabiskan waktu kosongnya untuk melakukan aktivitas kesukaannya dan merasakan kebahagiaan melalui hobi didalam rumah seperti menanam tanaman, mengatur rumah, membuat makanan sehat dan berolahraga. P2 memiliki hobi pada kegiatan di dalam rumah yaitu memasak. Namun sedikit terhambat karena waktu partisipan yang banyak dihabiskan di kantor sehingga partisipan memutuskan untuk mengajarkan keponakan hobi yang dimilikinya yaitu memasak. Kedua partisipan sama-sama memiliki waktu untuk melakukan hobi. Menurut Seligman (2005) keterlibatan penuh bukan hanya 
pada karier, tetapi juga dalam aktivitas lain seperti hobi dan aktivitas bersama keluarga, melibatkan diri secara penuh bukan hanya fisik yang beraktivitas tetapi hati dan pikiran juga turut serta dalam aktivitas tersebut.

\section{Penemuan Makna Dalam Keseharian}

Kedua partisipan mampu menemukan makna dalam kesehariannya. Kedua partisipan memandang jatuh bangun dalam kehidupan itu merupakan hal yang biasa dan lewat peristiwa tersebut kedua partisipan dapat belajar untuk bisa lebih dewasa dalam menyikapi segala sesuatu, bangkit kembali dan belajar mensyukuri segala sesuatu yang diberikan Tuhan. Hal ini sejalan dengan teori Simonton (dalam Papalia, 2009) yang menyatakan bahwa pengalamanpengalaman menantang yang memperkuat kemampuan agar tetap gigih dan mampu mengatasi rintangan. P1 memandang kebahagiaannya itu melalui pendidikan yang tinggi, memiliki penghasilan, serta menjadi alat Tuhan melalui pekerjaannya. Sedangkan P2 juga mendapatkan kebahagiaan melalui kariernya. Bagi P2 kebahagiaan yang paling berarti baginya yaitu ketika dapat mengurus keponakannya yang dititipkan Tuhan dapat mencapai keberhasilan.

\section{Optimisme yang Realistis}

Kedua partisipan sama-sama memiliki pandangan yang optimis mengenai masa depan, memiliki impian dan harapan yang positif dan merasa puas dengan kehidupannya. P1 merasa cukup atas pencapaiannya dalam hal pendidikan dan pekerjaan. P1 memiliki harapan yaitu lebih bersungguh-sungguh dalam melakukan pekerjaannya agar dapat membawa berkat bagi orang lain. Keberhasilan bagi P1 ketika pekerjaannya sebagai seorang dokter itu dapat memberkati serta dirasakan oleh orang lain. P1 memandang hal-hal positif yang ada pada dirinya yaitu memiliki fisik yang sehat, selalu menyadari unttuk tetap rendah hati, belajar dari pengalamanpengalaman untuk menjadi lebih baik, memiliki keinginan untuk selalu belajar dan menyenangkan orang lain. Sedangkan itu bagi P2 sejauh ini partisipan menjalani segala sesuatu dengan penuh sukacita karena jika tidak maka tidak berhasil. P2 merasa sudah cukup puas atas pencapaiannya saat ini serta merasa puas dalam hal mendidik anak-anaknya (keponakan). P2 merasa berhasil ketika keponakannya itu berhasil. P2 mempunyai impian yaitu saat pensiun nanti partisipan sudah memiliki investasi sehingga meskipun tidak bekerja tetap menghasilkan penghasilan, selain itu P2 
juga ingin hidup bebas dan dapat travelling keliling dunia. Bagi P2 hal yang ada pada dirinya itu diberikan kemampuan sehingga bisa menjalani kehidupan dan melakukan apapun dengan penuh sukacita sehingga apa saja yang dilakukannya selalu berhasil. Hal-hal diatas menunjukkan bahwa kepuasan mungkin meningkat karena semakin tua, semakin tinggi gaji yang diperoleh, berada pada posisi yang lebih tinggi, dan memiliki lebih banyak jaminan kerja. Terdapat komitmen yang lebih besar terhadap pekerjaan seiring bertambahnya usia, kita bekerja dengan lebih serius, tingkat ketidakhadiran yang dapat dihindarkan semakin sedikit dan lebih banyak mencurahkan diri pada pekerjaan pada masa dewasa tengah daripada masa dewasa awal (Santrock, 2002).

\section{Resiliensi}

Kedua partisipan memiliki sedikit perbedaan cara untuk bangkit kembali setelah mengalami peristiwa menyedihkan. Banyak peristiwa kehidupan yang dialami oleh P1 yang membuat partisipan sempat jatuh beberapa kali, tetapi dapat bangkit kembali melalui membaca buku medis, buku rohani dan mendengarkan lagu rohani dengan begitu partisipan merasa bahwa Tuhan selalu bersama-sama dengannya. Sedangkan saat mengalami masalah P2 lebih terbuka kepada Tuhan dan diajarkan oleh kedua orangtua untuk selalu cerita kepada Tuhan disaat mengalami masalah, karena saat bercerita dengan Tuhan pasti ada solusi dan bangkit kembali. Hal ini menunjukkan bahwa kedua partisipan sama-sama memiliki kemampuan untuk memulihkan dan memberikan respon positif setelah mengalami peristiwa menyedihkan. P1 bangkit melalui aktivitasnya membaca buku (rohani dan medis) dan mendengarkan lagu rohani sedangkan P2 merasa bisa bangkit kembali disaat partisipan bercerita dengan Tuhan (berdoa). Hal ini sejalan dengan pengertian resiliensi menurut Harrington (2013) yang menyatakan bahwa resiliensi adalah kemampuan untuk memulihkan dan memberikan respon positif setelah mengalami peristiwa negatif.

\section{Faktor Religiusitas}

Faktor yang berpengaruh kuat menentukan kebahagiaan pada kedua partisipan yaitu faktor religiusitas. Kedua partisipan mampu merasakan kebahagiaan di dalam Tuhan. P1 selalu berdoa dan berbicara dengan Tuhan, merasa bahagia serta melihat pencapaiannya itu sebagai karunia Tuhan. P2 selalu berharap pada Tuhan karena saat jauh dan tidak memerlukan Tuhan maka P2 tidak 
memiliki kekuatan. Bagi P2 untuk sampai pada saat ini itu semua karena Tuhan. P2 selalu memulai segala sesuatu dengan berdoa. Menurut Seligman (2005) orang yang lebih religius lebih bahagia dan lebih puas terhadap kehidupan daripada orang yang tidak religius.

\section{PENUTUP}

\section{Kesimpulan}

Kebahagiaan merupakan konsep yang mengacu pada emosi serta aktifitas positif yang dirasakan oleh setiap individu tidak terkecuali bagi individu yang hidup melajang. Setiap individu memiliki faktor yang berbeda sehingga dapat mendatangkan kebahagiaan dalam hidupnya. Bagi wanita madya yang memutuskan untuk hidup melajang tetap dapat merasakan dan menemukan kebahagiaannya melalui terjalinnya hubungan yang positif dengan orang lain, melibatkan diri secara penuh pada kegiatan-kegiatan yang disukai, menemukan makna dalam keseharian, memiliki sikap optimis dan mampu bangkit kembali setelah mengalami peristiwa-peristiwa yang menyedihkan (resiliensi).

Selain itu, faktor religiusitas turut memengaruhi kebahagiaan dari wanita dewasa madya yang memutuskan hidup melajang. Faktor religiusitas sangat penting dalam kehidupan karena kedua partisipan akan mendapatkan kekuatan dan mengucap syukur atas kehidupan yang sudah diberikan oleh Tuhan. Berdoa merupakan kunci sehingga dapat menjalani segala proses kehidupan dengan penuh sukacita yang membawa pada kebahagiaan.

\section{Saran}

Penelitian ini masih memiliki beberapa keterbatasan. Maka dari itu saran bagi penelitian selanjutnya yaitu lebih baik untuk menambah jumlah partisipan dengan karakteristik partisipan yang berbeda dari penelitian ini sehingga dapat memunculkan tema dan faktor-faktor baru yang memengaruhi gambaran kebahagiaan pada wanita dewasa madya yang memutuskan hidup melajang. Selain itu, pentingnya untuk melakukan wawancara dengan significant others yang dimiliki partisipan seperti teman dekat, orangtua dan keluarga sehingga lebih mendukung keakuratan data serta melihat secara objektif bagaimana keseharian yang dijalani oleh wanita dewasa madya yang memutuskan untuk hidup melajang.

\section{DAFTAR PUSTAKA}

Badan Pusat Statistik. 2016. Nikah, Talak, Dan Cerai Serta Rujuk 2012-2015.

Harrington, R. 2013. Stress, Health, And Well Being Thriving In The $21^{\text {st }}$ 
Century. USA: Wadsworth cengange learning.

Herdiansyah, Haris. 2015. Metodologi Penelitian Kualitatif Untuk Ilmu Psikologi. Jakarta: Salemba Humanika

Hidayatullah, M. S., \& Larassaty. R. M. 2017. Makna bahagia Pada Lajang Dewasa Madya. Jurnal ecopsy, 4, 71-76.

Hurlock, E. B. 1999. Psikologi Perkembangan. Jakarta. Penerbit Erlangga.

Papalia., Olds., Feldman. 2009. Human Development: Perkembangan Manusia. Jakarta: Salemba humanika.

Patnani, M. 2012. Kebahagiaan Pada Perempuan. Jurnal Psikogenesis, 1, 56-64.

Santrock, W. J. 2002. Life Span Development: Perkembangan Masa Hidup. Jakarta: Penerbit Erlangga.

Sari, E. V. (15 Agustus 2017). Survei BPS: Orang Lajang Indonesia Paling Bahagia. Cnnindonesia.
Seligman, M.E.P. 2002. Authentic Happiness: Using The New Positive Psychology To Realize Your Potential For Lasting Fulfillment. New York: Free press.

Seligman, M.E.P. 2005. Authentic Happiness: Menciptakan Kebahagiaan Dengan Psikologi Positif. Bandung: Mizan Media Utama.

Seligman, M.E.P. 2013. Beyond Authentic Happiness: Menciptakan Kebahagiaan Dengan Psikologi Positif. Bandung: Mizan Media Utama.

Septiana, M., \& Syafiq, M. 2013. Identitas Lajang (Single Identity) Dan Stigma: Studi Fenomenologi Perempuan Lajang di Surabaya. Jurnal Psikologi Teori \& Terapan, 4, 71-86.

Smith, J. A. \& Osborn, M. 2009. Analisis Fenomenologi Interpretatif Dalam J. A. Smith.(ed.). Psikologi Kualitatif: Panduan Praktis Metode Riset. (edisi terjemahan). Yogyakarta: Pustaka Pelajar.

Sutanto, P., \& Haryoko, F. 2010. Gambaran Konsep Diri Wanita Berkarier Sukses Yang Belum Menikah. Insan, 12, 11-20. 